\title{
Humusica 2, article 10: Histic humus systems and forms - Key of classification*
}

Augusto Zanella ${ }^{a}{ }^{\dagger}$, Rein De Waal ${ }^{b}$, Bas Van Delft ${ }^{b}$, Jean-François Ponge ${ }^{c}$, Chiara Ferronato ${ }^{d}$, Maria De Nobili ${ }^{\mathrm{e}}$, Renée-Claire Le Bayon ${ }^{\mathrm{f}}$, Anna Andreetta $^{\mathrm{g}}$, Raimo Kõlli ${ }^{\mathrm{h}}$

${ }^{a}$ University of Padua, Italy

${ }^{\mathrm{b}}$ University of Wageningen, The Netherlands

${ }^{\mathrm{c}}$ Muséum National d'Histoire Naturelle, Paris, France

${ }^{\mathrm{d}}$ University of Bologna, Bologna, Italy

e University of Udine, Udine, Italy

${ }^{\mathrm{f}}$ University of Neuchâtel, Switzerland

${ }^{\mathrm{g}}$ University of Firenze, Italy

${ }^{\mathrm{h}}$ Institute of Agricultural \& Environmental Sciences, Tartu, Estonia

Keywords: Humus; Histic humus; Histic humus classification; Humusica; Peat; Moor

\section{ABSTRACT}

This paper corresponds to an illustrated field key of classification of Histic humipedon. Vocabulary and diagnostic horizon definitions are in Humusica 2, article 9. The process of classification can follow a step by step way or simply be realised choosing the right diagnostic horizon on a table and composing the whole profile as in a game of construction. Examples of real profiles are given for comparison with the ones people can find in the field.

\footnotetext{
* Suggested background music while reading: Occhi chorni (Очи Чёрные) on accordion (Russian Gypsy music): https://www.youtube.com/watch?v=MkUOxJv4jmA.

${ }^{\dagger}$ Corresponding author.

E-mail addresses: augusto.zanella@unipd.it (A.Zanella), rein.dewaal@wur.nl (R. de Waal), bas.vandelft@wur.nl (B. Van Delft), ponge@mnhn.fr (J.-F. Ponge), chiara.ferronato2@unibo.it (C. Ferronato), maria.denobili@uniud.it (M. De Nobili), claire.lebayon@unine.ch (R.-C. Le Bayon), anna.andreetta@unifi.it (A. Andreetta), raimo.kolli@emu.ee (R. Kõlli).
} 


\section{Introduction}

Humusica recovers keys of classification published in preceding works (Jabiol et al., 2013; Zanella et al., 2011, 2009). Here, we have introduced important improvements at the level of vocabulary, précising terms and diagnostic horizons. The gradual shift from Histic systems to Terrestrial systems on one side and to Submerged systems on the other (Humusica 2, article 12), gives more functionality and practical value to the whole classification. We distinguished fens from bogs. Fens are generally covered by grasses and sedges. They have greater water exchange (oxygenated water) and a water richer in nutrients coming rather from small streams and groundwater. Bogs are usually acid systems, covered with Sphagnum peat mosses. Their oxygen content in water is very low (hypoxia) and water mainly comes rather from rain and snow. Less known is the subdivision between large and small systems, as illustrated in Figure 1. Both distinctions, fens and bogs on one side, large and small systems on the other, interfere and generate the Histic humus systems we enumerate here down. Please refer to specialized publications for investigations about the processes of formation of these soils, some among many (Bock and Köthe, 2008; Boixadera et al., 2003; Christiansen et al., 2012; Clarke et al., 2003; Curmi et al., 1998, 1993; Ferronato et al., 2016; Hong et al., 2016; Hussain and Swindale, 1970; Jungkunst et al., 2008; Jungkunst and Fiedler, 2007; Kögel-Knabner et al., 2010; Kolli, 2011; Kraus and Aslan, 1993; Kust, 1995; Lange et al., 2011; Licht et al., 2014; Loustau and Toutain, 1987; Mafra et al., 2007; Munch and Ottow, 1983; Nawaz et al., 2014; Ottow and Munch, 1978; Rashid and Schaefer, 1985; Rawls et al., 2003; Spohn et al., 2016; Targulian and Krasilnikov, 2007; Trebitz et al., 2005; Vicca et al., 2009; Vittori Antisari et al., 2016; Well et al., 2003; Winkler et al., 2016), for more detailed field descriptions and soil parameters surveys, or present time challenges involving submerged soils, among many works (Adhikari and Hartemink, 2016; Balks and Zabowski, 2016; Batjes, 2014; Bou Kheir et al., 2010; Canarache et al., 2006; Chaplot et al., 2003, 2001; Heinemeyer et al., 2010; Jahn et al., 2006; Kolay, 2007; Kutílek and Nielsen, 2015; Malone et al., 2017; Mishra and Kuhlman, 2013; Nieveen et al., 2005; Parsekian et al., 2012; Rudiyanto et al., 2016; Soil Science Division Staff, 2017; Stockmann et al., 2013, 2016; Zhang et al., 2016).

\section{General features and distribution of the histic humus systems}

\subsection{General features and distribution of Anmoor}

- Ecological conditions: wet base-rich soils or soils enriched through base-rich groundwater in brook valley systems (small rivers, brooks, small streams and floodplains, not in dynamic floods or inundations with fast currents); temperate climate and/or non-acid siliceous, or calcareous parent material and/or easily biodegradable litter $(\mathrm{C} / \mathrm{N}<30)$ and/or no major environmental constraint;

- Dominant actors of organic matter biodegradation: anaerobic bacteria, anecic and large endogeic earthworms; 
- Actors action: fast litter decomposition and incorporation in the upper soil layers and consequent disappearance of litter from the topsoil ( $\leq 3$ years), potential carbon stocked in the $A$ horizon;

- pHwater of the A horizon: generally $\geq 5$;

- Key diagnostic features (morpho-functional result of specific biological activities): $\mathrm{H}$ never presents, anA muddy or biomacrostructured in very dried period of the year, sharp transition $(<3$ $\mathrm{mm}$ ) between organic and organo-mineral horizons.

\subsection{General features and distribution of Saprimoor}

- Ecological conditions: moist base-rich soils in brook valley systems and fens (large floodplains, large extended systems partly characterized by processes of sedimentation) and drained fens in floodplains and dynamic brook valleys; mild to moderately cold climate, generally not in acid water conditions;

- Dominant actors of biodegradation: enchytraeids, collembolans and epigeic earthworms; fungi;

- Actors action: slow biodegradation (2-7 years), carbon stocked in both organic and organicmineral horizons;

- pHwater of the A horizon: generally $>5$;

- Key diagnostic features: HF or HM never present, nozHS possible and even dominant in some cases, anA possible in concomitance with IHS.

\subsection{General features and distribution of Amphimoor}

- Ecological conditions: moderately moist base-poor soils in brook valley systems or base-rich soils in half-drained fens and eutrophic or desiccated fens with growing influence of stagnating rainwater; contrasting climate conditions (dry summer, rainy autumn), generally in acidocline water, with growing influence in desiccated fens;

- Dominant actors of biodegradation: enchytraeids, collembolans, mites and earthworms; fungi;

- Actors action: slow biodegradation (2-7 years), high carbon content in both organic and organic-mineral horizons;

- pHwater of the A horizon: generally $<5$; 
- Key diagnostic features (morpho-functional result of specific biological activities): HS always present, plus $\mathrm{HM}$ or $\mathrm{HF}$ following the increasing acidity of the water.

\subsection{General features and distribution of Mesimoor}

- Ecological conditions: wet moderately base-poor soils in brook valley systems, or baseenriched soils of drained, previously base-poor bogs, bogs in floodplains and brook valleys fed by surface or mesotrophic groundwater (not dynamic); base poor soils filled by acid to mesotrophic water;

- Dominant actors of biodegradation: enchytraeids, collembolans, mites and epigeic earthworms; fungi;

- Actors action: very slow biodegradation (> 7 years), carbon stocked in organic horizons;

- pHwater of the A horizon < 5;

- Key diagnostic features (morpho-functional result of specific biological activities): nozHS always present, thickness negatively correlated to the one of $\mathrm{HM}$ and $\mathrm{HF}$ present horizons.

\subsection{General features and distribution of Fibrimoor}

- Ecological conditions: wet very base-poor soils in brook valley systems and bogs, rain fed moors, bogs, isolated parts of fens and brook valleys; base-poor, rain fed soils;

- Dominant actors of biodegradation: fungi and other non-faunal processes;

- Actors action: very slow biodegradation (> 7 years), carbon rather in organic horizons;

- pHwater < 4.5;

- Key diagnostic features (morpho-functional result of specific biological activities): HF always dominant, HM and nozHS possible.

\section{Step by step key of classification of histic humus systems}

Humus forms in which faunal activities and decomposition of organic matter are well visible but are or have been strongly limited and/or influenced by anaerobic conditions.

Anmoor 
Humus forms of wet base-rich soils or soils enriched by base-rich groundwater around springs and in non-dynamic parts of brook or river valley systems (parts of floodplains, lacking dynamic floods or inundations with fast currents). To be identified as Anmoor, the topsoil must display the following properties:

1. presence of a dominant anA organo-mineral horizon; and

2. zoHS, IHS possible but never thicker than anA

Saprimoor

Humus forms of moist base-rich mineral soils or eutrophic organic soils in mostly drained brook valley systems or fens and floodplains. To be identified as Saprimoor, the topsoil must display the following properties:

1. HF or HM never present within the control section; and

2. presence of zoHS or IHS at the top of the profile; and

3. nozHS possible but thinner than zoHS; and

4. very active biodegradation of plant remains and their complete integration in an organic-mineral horizon.

Amphimoor

Humus forms of moderately moist base-poor soils in brook valley systems or partly base-rich soils in half-drained fens. To be identified as Amphimoor, the topsoil must display the following properties:

1. zoHS horizon dominant in thickness and present with HF or HM or HF and HM; and

2. HF and HM thinner than zoHS within the control section (first $40 \mathrm{~cm}$ below the surface); and

3. active to very active biodegradation of organic matter and mixing with organic-mineral matter

Mesimoor

Humus forms of wet moderately base-poor organic soils in brook valley systems, or baseenriched soils of drained previously base-poor fens, or bogs. To be identified as Mesimoor, the topsoil must display the following properties:

1. HF possible but never dominant; and

2. HM or nozHS present and thicker than other horizons; and

3. organic matter degradation more active/efficient than in Fibrimoor

Fibrimoor

Humus forms of wet very base-poor organic soils in brook valley systems and bogs. To be identified as Mesimoor, the topsoil must display the following properties: 
1. presence of a thick HF horizon; and

2. HM possible but never thicker than HF; and

3. degradation of organic matter slow or inhibited

\section{Step by step key of classification of histic humus forms}

Topsoils (organic and organic-mineral horizons) submerged and/or water saturated for more than a few months per year, and characterized by the presence of $\mathrm{H}$ horizon AND:

\section{Step 1}

1. HF horizon present and thick; and

2. HS absent

AND either

1. HM absent: Eufibrimoor (Figs. 6 and 7),

2. OR: HM present but never thicker than HF, nozHS absent: Humifibrimoor,

3. OR: HM present but never thicker than HF, nozHS present: Saprifibrimoor,

OR

Step 2

Other topsoils (organic and organo-mineral horizons) submerged and/or water saturated for more than a few months per year, and characterized by the presence of $\mathrm{H}$ horizon AND:

1. nozHS and HM always present; HF possible but never thicker than HM

AND either

- HF present; thickness: HM > HF > nozHS: Fibrimesimoor,

- OR: HF present; thickness: HM > nozHS > HF: Eumesimoor,

- OR: HF absent, thickness: HM > nozHS: Humimesimoor (Fig. 5)

- OR: HF absent, thickness: nozHS > HM: Saprimesimoor,

OR

Step 3

Other topsoils (organic and organo-mineral horizons) submerged and/or water saturated for more than a few months per year, and characterized by the presence of an $\mathrm{H}$ horizon AND: 
1. zoHS horizon present and dominant in thickness; and

2. $\mathrm{HF}$ and $\mathrm{HM}$ thinner than zoHS within the control section (first $40 \mathrm{~cm}$ below the surface), IHS possible

AND either

- HF absent, HM possible: Humiamphimoor,

- OR: HF present, HM possible; thickness: zoHS > HF > HM: Euamphimoor,

- OR: HF present, HM absent; thickness: zoHS > HF: Fibriamphimoor (Fig. 4),

OR

Step 4

Other topsoils (organic and organo-mineral horizons) submerged and/or water saturated for more than a few months per year, or organic and drained, and characterized by the presence of anA or $\mathrm{H}$ horizon(s)

AND:

1. HF or HM never present within the control section; and

2. zoHS or IHS present at the top of the profile; and

3. nozHS possible but thinner than zoHS,

AND either

- IHs present and thicker than anA: Limisaprimoor (Fig. 3),

- OR: zoHS present and thicker than nozHS: Eusaprimoor,

- OR: nozHS: Oligosaprimoor

OR

Step 5

Other topsoils (organic and organo-mineral horizons) submerged and/or water saturated for more than a few months per year, and characterized by the presence of anA or $\mathrm{H}$ horizon(s) AND:

1. anA organo-mineral horizon present and dominant; and

2. zoHS and IHS possible but never thicker than anA

AND either

- H absent: Euanmoor (Fig. 2),

- OR: IHS present and thinner than anA: Limianmoor, 
- OR: zoHS present and thinner than anA: Saprianmoor

The name of a humus forms is usually written in a single word, beginning with a capital letter. Example: Saprianmoor, but not Sapri Anmoor, not Sapri-Anmoor, not Sapri-anmoor.

\section{Key of classification of humus forms}

The key of classification corresponds to a large table formed by lines of diagnostic horizons and columns of humus systems parted in humus forms. As the relative thickness of the horizons is important for the classification of the profile, the presence of the horizon in a given column is indicated by a grey colour covering $1 / 3,2 / 3$ or $3 / 3$ of the space present in the corresponding case. We preferred to cut vertically the table for presenting one by one the different humus systems. An example of lecture is given for the Anmoor table in 4.1. The sequence of diagnostic horizons listed on the left of the table does not change from a system to another. The first column reports also hydromorphic horizons which, when present in addition to the typical horizons, allow to assign the profile to an intergrade between Histic and Terrestrial system. Intergrade humipedons will be detailed in an article dedicated to the relationships between humipedons and environment (Humusica 2, article 11).

\subsection{Anmoor humus forms (Euanmoor, Limianmoor, Saprianmoor)}

The Anmoor humus system is represented by three humus forms (Figs. 2a, b). The humus form Euanmoor is characterised by a single anA horizon. This horizon is present even in Limianmoor and Saprianmoor forms, but accompanied by thinner IHS or HS horizons respectively. Instead of laying on a mineral horizon (generally a submersed, reduced, grey and rich in clay horizon), the anA horizon would lay on a gzoA horizon (indicated as possible hydromorphic horizon in Fig. 2a) in case of an Epihistic intergrade.

\subsection{Saprimoor humus forms (Limisaprimoor, Eusaprimoor, Oligosaprimoor)}

The Saprimoor humus system is represented by three humus forms (Figs. 3a, b). A typical Eusaprimoor is made of a thick, black HS horizon. A Limisaprimoor is instead characterized by a dominant in thickness IHS, laying on a thin anA (these two horizons may generate on a thick gzoA horizon of an intergrade Epihisto Limisaprimoor). Oligosaprimoor generates in acid conditions and is characterized by non zoogenic horizons (typical nozHS and gnozA or AE in Epihisto intergrades). 


\subsection{Amphimoor humus forms (Humiamphimoor, Euamphimoor, Fibriamphimoor)}

The Amphimoor humus system is represented by three humus forms (Figs. 3a, b). An Amphimoor corresponds to a less active Saprimoor on which may periodically or permanently establish HM or HF horizons. It is possible to share Euamphimoor (thickness of HM horizon $\leq 1 / 2 \mathrm{HS}$ ) from Humiamphimoor (thickness of HM horizon $>1 / 2 \mathrm{HS}$ ) and from Fibriamphimoor (presence of HF instead of HM horizon). In any case, HS horizon is thicker than the other horizons. Epihisto Amphimoors are very common, showing a zoogenic hydromorphic A horizon basement (gzoA).

\subsection{Mesimoor humus forms (Saprimesimoor, Humimesimoor, Eumesimoor, Fibrimesimoor)}

The Mesimoor humus system is represented by four humus forms (Figs. 5a, b). A Mesimoor corresponds to a Histic system with non zoogenic nozHS horizons. In a Saprimesimor, nozHS is thicker than $\mathrm{HM}$; in a Humimesimoor HM > nozHS. In both, Saporimesimoor and Humimesimoor, HF is absent. The less active Mesimoors show an HF horizon, which is less thick in Eumesimoor ( $\leq 1 / 2 \mathrm{HM})$ than in Fibrimesimoor (> $1 / 2 \mathrm{HM}$ ). HF horizon never dominates; nozHS and $\mathrm{HM}$ are always present. Epihisto Mesimoors are possible, showing at the bottom non zoogenic hydromorphic $A$ or $A E$ horizons (gzoA or gAE).

\subsection{Fibrimoor humus forms (Saprifibrimoor, Humifibrimoor, Eufibrimoor)}

The Fibrimoor humus system is represented by three humus forms (Figs. 6a, b). A Fibrimoor corresponds to a Histic system with dominant in thickness HF horizon. It is called Saprifibrimoor when nozHS and $\mathrm{HM}$ are also present and nozHS is thicker than HM (avoiding confusion with Eumesimoor, where HM dominates (thickness) on nozHS, and even on HF); it becomes Humifibrimoor when nozHS disappears, letting in place HM and HF horizons; an Eufibrimoor is exclusively made of HF horizon. Epihisto Fibrimoors are possible, showing at the bottom non zoogenic hydromorphic A or AE horizons (gzoA or gAE). About $30 \%$ of Estonia is covered by peat or peaty soils (Masing et al., 2000) and prof. Kõlli furnished some pictures of humipedon particular and plant cover (Figs. 7a-c).

\section{References}

Adhikari, K., Hartemink, A.E., 2016. Linking soils to ecosystem services: a global review. Geoderma 262, 101-111. 
Balks, M.R., Zabowski, D., 2016. Celebrating Soil: Discovering Soils and Landscapes. Springer International Publishing, Cham.

Batjes, N.H., 2014. Total carbon and nitrogen in the soils of the world. Eur. J. Soil Sci. 65, 10-21.

Bock, M., Köthe, R., 2008. Predicting the depth of hydromorphic soil characteristics influenced by ground water. Hambg. Beiträge Phys. Geogr. Landschaftsökol. 19, 13-22.

Boixadera, J., Poch, R.M., García-González, M.T., Vizcayno, C., 2003. Hydromorphic and clay-related processes in soils from the Llanos de Moxos (northern Bolivia). Catena 54, 403-424.

Bou Kheir, R., Bøcher, P.K., Greve, M.B., Greve, M.H., 2010. The application of GIS based decisiontree models for generating the spatial distribution of hydromorphic organic landscapes in relation to digital terrain data. Hydrol. Earth Syst. Sci. 14, 847-857.

Canarache, A., Vintila, I.I., Munteanu, I., 2006. Elsevier's Dictionary of Soil Science: Definitions in English with French, German, and Spanish Word Translations. Elsevier, Amsterdam.

Chaplot, V., Bernoux, M., Walter, C., Curmi, P., Herpin, U., 2001. Soil carbon storage prediction in temperate hydromorphic soils using a morphologic index and digital elevation model. Soil Sci. $166,48-60$.

Chaplot, V., Walter, C., Curmi, P., 2003. Testing quantitative soil-landscape models for predicting the soil hydromorphic index at a regional scale. Soil Sci. 168, 445-454.

Christiansen, J.R., Gundersen, P., Frederiksen, P., Vesterdal, L., 2012. Influence of hydromorphic soil conditions on greenhouse gas emissions and soil carbon stocks in a Danish temperate forest. For. Ecol. Manag. 284, 185-195.

Clarke, S.J., Bruce-Burgess, L., Wharton, G., 2003. Linking form and function: towards an ecohydromorphic approach to sustainable river restoration. Aquat. Conserv. Mar. Freshw. Ecosyst. 13, 439-450.

Curmi, P., Durand, P., Gascuel-Odoux, C., Merot, P., Walter, C., Taha, a, 1998. Hydromorphic soils, hydrology and water quality: spatial distribution and functional modelling at different scales. Nutr. Cycl. Agroecosyst. 50, 127-142.

Curmi, P., Widiatmaka, Pellerin, J., Ruellan, A., 1993. Saprolite influence on formation of well-drained and hydromorphic horizons in an acid soil system as determined by structural analysis. Dev. Soil Sci. 22, 133-140.

Ferronato, C., Falsone, G., Natale, M., Zannoni, D., Buscaroli, A., Vianello, G., Vittori Antisari, L., 2016. Chemical and pedological features of subaqueous and hydromorphic soils along a hydrosequence within a coastal system (San Vitale Park, Northern Italy). Geoderma 265, 141-151.

Heinemeyer, A., Croft, S., Garnett, M.H., Gloor, E., Holden, J., Lomas, M.R., Ineson, P., 2010. The MILLENNIA peat cohort model: predicting past, present and future soil carbon budgets and fluxes under changing climates in peatlands. Clim. Res. 45, 207-226. 
Hong, H., Fang, Q., Cheng, L., Wang, C., Churchman, G.J., 2016. Microorganism-induced weathering of clay minerals in a hydromorphic soil. Geochim. Cosmochim. Acta 184, 272-288.

Hussain, M.S., Swindale, L.D., 1970. A morphological and mineralogical study of the gray hydromorphic soils of the Hawaiian islands. Pac. Sci. 24, 543-553.

IUSS Working Group WRB, 2014. World Reference Base for Soil Resources 2014, Update 2015. International Soil Classification System for Naming Soils and Creating Legends for Soil Maps. Food and Agriculture Organisation of the United Nations, Rome, Italy.

Jabiol, B., Zanella, A., Ponge, J.F., Sartori, G., Englisch, M., van Delft, B., De Waal, R., Le Bayon, R.C., 2013. A proposal for including humus forms in the World Reference Base for Soil Resources (WRB-FAO). Geoderma 192, 286-294.

Jahn, R., Blume, H.-P., Asio, V.B., Spaargaren, O., Schad, P., Langohr, R., Brinkman, R., Nachtergaele, F.O., Pavel Krasilnikov, R., 2006. Guidelines for Soil Description, Fourth edition. Food And Agriculture Organization of The United Nations, Rome, Italy.

Jungkunst, H.F., Fiedler, S., 2007. Latitudinal differentiated water table control of carbon dioxide, methane and nitrous oxide fluxes from hydromorphic soils: feedbacks to climate change. Glob. Change Biol. 13, 2668-2683.

Jungkunst, H.F., Flessa, H., Scherber, C., Fiedler, S., 2008. Groundwater level controls $\mathrm{CO}_{2}, \mathrm{~N}_{2} \mathrm{O}$ and $\mathrm{CH}_{4}$ fluxes of three different hydromorphic soil types of a temperate forest ecosystem. Soil Biol. Biochem. 40, 2047-2054.

Kögel-Knabner, I., Amelung, W., Cao, Z., Fiedler, S., Frenzel, P., Jahn, R., Kalbitz, K., Kölbl, A., Schloter, M., 2010. Biogeochemistry of paddy soils. Geoderma 157, 1-14.

Kolay, A.K., 2007. Soil Genesis, Classification Survey and Evaluation. Atlantic, New Delhi.

Kõlli, R., 2011. Euroopa huumusvormide klassifikatsiooni väljatöötamisest. Agronoomia 2010/2011, 37-44.

Kraus, M., Aslan, A., 1993. Eocene hydromorphic paleosols: significance for interpreting ancient floodplain processes. J. Sediment. Res. 63, 453-463.

Kust, G.S., 1995. On the post-hydromorphic evolution of the soil cover in arid fluviatile plains. Eurasian Soil Sci. 27, 51-70.

Kutílek, M., Nielsen, D.R., 2015. Soil: the Skin of the Planet Earth. Springer, Dordrecht.

Lange, B., Germann, P.F., Lüscher, P., 2011. Runoff-generating processes in hydromorphic soils on a plot scale: free gravity-driven versus pressure-controlled flow. Hydrol. Process. 25, 873-885.

Licht, A., Cojan, I., Caner, L., Soe, A.N., Jaeger, J.J., France-Lanord, C., 2014. Role of permeability barriers in alluvial hydromorphic palaeosols: the Eocene pondaung formation, Myanmar. Sedimentology 61, 362-382. 
Loustau, D., Toutain, F., 1987. Micromorphologie et fonctionnement de quelques humus des formes Hydromull et Anmoor de l'Est de la France. In: AFES (Ed.), Réunion Internationale de Micromorphologie des Sols 7. AFES, Plaisir, pp. 385-389.

Mafra, A.L., Senesi, N., Brunetti, G., Miklós, A.A.W., Melfi, A.J., 2007. Humic acids from hydromorphic soils of the upper Negro river basin, Amazonas: chemical and spectroscopic characterisation. Geoderma 138, 170-176.

Malone, B.P., Minasny, B., McBratney, A.B., 2017. Using R for Digital Soil Mapping. Springer International Publishing, Cham.

Masing, V., Paal, J., Kuresoo, A., 2000. Biodiversity of Estonian wetlands. In: In: Gopal, B., Junk, W.J. (Eds.), Biodiversity in Wetlands: Assessment, Function and Conservation, volume 1. Backhuys, Leiden, pp. 259-279.

Mishra, P.K., Kuhlman, K.L., 2013. Advances in Hydrogeology. Springer, New York.

Munch, J.C., Ottow, J.C.G., 1983. Reductive transformation mechanism of ferric oxides in hydromorphic soils reductive transformation mechanism of ferric oxides in hydromorphic soils. Ecol. Bull. 35, 383-394.

Nawaz, M.F., Bourrie, G., Gul, S., 2014. Factors affecting redox reactions in hydromorphic soils: a review. Pakistan J. Agric. Sci. 51, 517-523.

Nieveen, J.P., Campell, D.I., Schipper, L.A., Blair, I.J., 2005. Carbon exchange of grazed pasture on drained peat soil. Glob. Change Biol. 11, 607-618.

Ottow, J.C.G., Munch, J.C., 1978. Mechanism of reductive transformations in the anaerobic microenvironment of hydromorphic soils. In: Krumbein, W.E. (Ed.), Environmental Biogeochemistry and Geomicrobiology. Ann Arbor Science Publishers, Ann Arbor, pp. 483491.

Parsekian, A.D., Slater, L., Ntarlagiannis, D., Nolan, J., Sebesteyen, S.D., Kolka, R.K., Hanson, P.J., 2012. Uncertainty in peat volume and soil carbon estimated using ground-penetrating radar and probing. Soil Sci. Soc. Am. J. 76, 1911-1918.

Rashid, G.H., Schaefer, R., 1985. The seasonal pattern of carbon dioxide evolution from two temperate forest catena soils. Rev. Ecol. Biol. Sol. 22, 419-431.

Rawls, W.J., Pachepsky, Y.A., Ritchie, J.C., Sobecki, T.M., Bloodworth, H., 2003. Effect of soil organic carbon on soil water retention. Geoderma 116, 61-76.

Rudiyanto, Minasny, B., Setiawan, B.I., 2016. Further results on comparison of methods for quantifying soil carbon in tropical peats. Geoderma 269, 108-111.

Soil Science Division Staff, 2017. Soil Survey Manual. Government Printing Office, Washington, D.C.

Spohn, M., Klaus, K., Wanek, W., Richter, A., 2016. Microbial carbon use efficiency and biomass turnover times depending on soil depth: implications for carbon cycling. Soil Biol. Biochem. $96,74-81$. 
Stockmann, U., Adams, M.A., Crawford, J.W., Field, D.J., Henakaarchchi, N., Jenkins, M., Minasny, B., McBratney, A.B., Courcelles, V.R., Singh, K., Wheeler, I., Abbott, L., Angers, D.A., Baldock, J., Bird, M., Brookes, P.C., Chenu, C., Jastrow, J.D., Lal, R., Lehmann, J., O’Donnell, A.G., Parton, W.J., Whitehead, D., Zimmermann, M., 2013. The knowns, known unknowns and unknowns of sequestration of soil organic carbon. Agric. Ecosyst. Environ. 164, 80-99.

Stockmann, U., Jang, H.J., Minasny, B., McBratney, A.B., 2016. The effect of soil moisture and texture on Fe concentration using portable X-ray fluorescence spectrometers. In: Hartemink, A.E., Minasny, B. (Eds.), Digital Soil Morphometrics. Springer International Publishing, Cham.

Targulian, V.O., Krasilnikov, P.V., 2007. Soil system and pedogenic processes: self-organization, time scales, and environmental significance. Catena 71, 373-381.

Trebitz, A.S., Morrice, J. a., Taylor, D.L., Anderson, R.L., West, C.W., Kelly, J.R., 2005. Hydromorphic determinants of aquatic habitat variability in Lake Superior coastal wetlands. Wetlands 25 , 505-519.

Vicca, S., Janssens, I.A., Flessa, H., Fiedler, S., Jungkunst, H.F., 2009. Temperature dependence of greenhouse gas emissions from three hydromorphic soils at different groundwater levels. Geobiology 7, 465-476.

Vittori Antisari, L., De Nobili, M., Ferronato, C., Natale, M., Pellegrini, E., Vianello, G., 2016. Hydromorphic to subaqueous soils transitions in the central Grado lagoon (Northern Adriatic Sea, Italy). Estuar. Coast. Shelf Sci. 173, 39-48.

Well, R., Augustin, J., Meyer, K., Myrold, D.D., 2003. Comparison of field and laboratory measurement of denitrification and $\mathrm{N}_{2} \mathrm{O}$ production in the saturated zone of hydromorphic soils. Soil Biol. Biochem. 35, 783-799.

Winkler, P., Kaiser, K., Kölbl, A., Kühn, T., Schad, P., Urbanski, L., Fiedler, S., Lehndorff, E., Kalbitz, K., Utami, S.R., Cao, Z., Zhang, G., Jahn, R., Kögel-Knabner, I., 2016. Response of vertisols andosols, and alisols to paddy management. Geoderma 261, 23-35.

Zanella, A., Jabiol, B., Ponge, J.F., Sartori, G., De Waal, R., Van Delft, B., Graefe, U., Cools, N., Katzensteiner, K., Hager, H., Englisch, M., Brêthes, A., 2009. Toward a European humus forms reference base. Stud. Trentini Sci. Nat. 85, 145-151.

Zanella, A., Jabiol, B., Ponge, J.F., Sartori, G., De Waal, R., Van Delft, B., Graefe, U., Cools, N., Katzensteiner, K., Hager, H., Englisch, M., 2011. A European morphofunctional classification of humus forms. Geoderma 164, 138-145.

Zhang, G.-L., Brus, D., Liu, F., Song, X.-D., Lagacherie, P., 2016. Digital Soil Mapping Across Paradigms, Scales and Boundaries. Springer, Singapore. 


\section{Figure captions}

Fig. 1. Large or small systems of submerged humipedons. The water table also interferes and generally has a larger fluctuation at the level of Amphimoor and Saprimoor systems (prepared by R. De Waal, A. Zanella, J.F. Ponge and R. Kõlli).

Fig. 2. Anmoor: a) diagnostic horizons presence and relative thickness in Anmoor humus forms; b) thick Euanmoor, about $30 \mathrm{~cm}$ of dark anA lying on lighter and more compact sandy clay deposit. Scale: the sampling probe is $9 \mathrm{~cm}$ large (photograph: R. De Waal).

Fig. 3. Saprimoor: a) diagnostic horizons presence and relative thickness in Saprimoor humus forms; b) Limisaprimoor near Reu (The Netherlands) in higher grounds, Black IHS (0-25 cm), brown anA (25-45 cm). Mean highest ground water level $25 \mathrm{~cm}$ under ground level; lowest mean ground water level $65 \mathrm{~cm}$. Scale: the sampling probe is $9 \mathrm{~cm}$ large (photograph: R. De Waal).

Fig. 4. Amphimoor: a) diagnostic horizons presence and relative thickness in Amphimoor humus forms; b) Fibriamphimoor around an oligotrophic bog, in a zone fed by ground water. $\mathrm{pH}$ $(\mathrm{KCL})$ is 3.6 in the fibric zone, however 5.5 the sapric zone. Scale: the sampling probe is $9 \mathrm{~cm}$ large. Fibric layer ( $\mathrm{HF}=0-10 \mathrm{~cm}$ ) on top of a sapric horizon (HS 10-40 cm). Eastern part of The Netherlands. The mean highest ground water level is $0 \mathrm{~cm}$ under ground level; the lowest mean ground water level is $40 \mathrm{~cm}$ (photograph: R. De Waal).

Fig. 5. Mesimoor: a) diagnostic horizons presence and relative thickness in Mesimoor humus forms; b) Humimesimoor in east of The Netherlands, in a depression fed by acidic iron saturated ground water. Scale: the sampling probe is $9 \mathrm{~cm}$ large. Dark brown HM horizon $(0-25 \mathrm{~cm})$, then brown nozHS $(25-40 \mathrm{~cm})$. The mean highest ground water level is $5 \mathrm{~cm}$ under ground level; the lowest mean ground water level is $25 \mathrm{~cm}$ (photograph: R. De Waal).

Fig. 6. Fibrimoor: a) diagnostic horizons presence and relative thickness in Fibrimoor humus forms; $b$ ) Eufibrimoor in wet heathland (Western part of The Netherlands). Ruler is $20 \mathrm{~cm}$. Horizon HF. The mean highest groundwater level is $3 \mathrm{~cm}$ under ground level; the lowest mean ground water level is $30 \mathrm{~cm}$ (photograph: R. De Waal).

Fig. 7. Fibrimoor in Estonian Tudu-Järvesoo bogs: a) treed ridge-hollow bog (sight at early spring); b) dominating plant associations on hummocks Calluno-Eriophoro-Sphagnetum fusci and on hollows Rhynchosporo-Scheuchzerio-Sphagnetum cuspidatum (Masing et al., 2000); c) Dystric Ombric Fibric Histosol (Hyperorganic) (according to IUSS Working Group WRB, 2014), corresponding to a slightly decomposed bog soil with an oligotrophic peat, by Estonian classification (Kõlli, 2011) (photographs: T. Kõlli). 
LARGE floodplains, large extended systems partly characterized by processes of sedimentation

BOCS, base-poor systems

Plants adapted to cold and acidic environments as sphagnum mosses, sundews, cotton grasses, sedges, cranberries; as trees, mainly pine, also spruce...
SMALL rivers, brooks, small streams and floodplains, not in dynamic floods or inundations with fast currents

\section{TRENDS}

FENS, base-rich to base-poor systems More varied plant associations, in meadows of sedges, grasses, reeds; trees as birch, black alder, spruce...

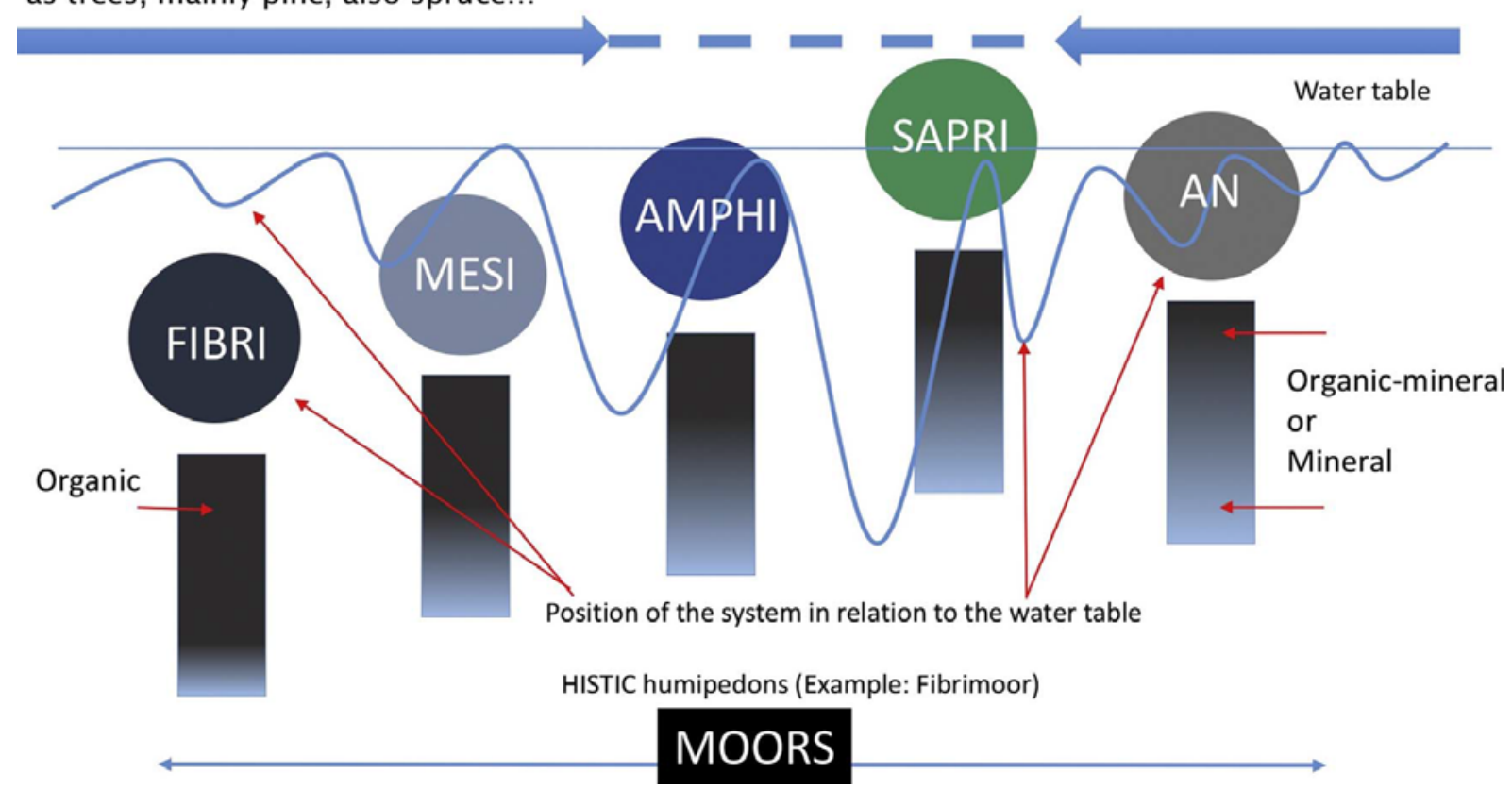

Fig. 1 
a

\begin{tabular}{|c|c|c|c|c|}
\hline \multicolumn{2}{|c|}{ DIAGNOSTIC HORIZONS } & \multicolumn{3}{|c|}{ ANMOOR } \\
\hline EPIHISTO & (typical) & Euanmoor & Limianmoor & Saprianmoor \\
\hline \multirow{9}{*}{$\begin{array}{l}\text { gOL, gOF possible } \\
\text { but not sufficient, } \\
\text { gOH sufficient for } \\
\text { using Epihisto } \\
\text { prefix }\end{array}$} & HF & & & \\
\hline & HM & & & \\
\hline & & & & \\
\hline & HS & & & \\
\hline & & & & \\
\hline & Thens & & & \\
\hline & & & & \\
\hline & & & & \\
\hline & an $A$ & & & \\
\hline \multirow{6}{*}{$\begin{array}{l}\text { gzoA (gmaA, } \\
\text { gmeA, gmiA), } \\
\text { gnozA, gAE } \\
\text { sufficient for } \\
\text { using Epihisto } \\
\text { prefix }\end{array}$} & PzoA & & & \\
\hline & & & & \\
\hline & gnozA & & & \\
\hline & & & & \\
\hline & gAE & & & \\
\hline & & & & \\
\hline
\end{tabular}

Possible hydromorphic $(\mathrm{g})$ terrestrial diagnostic horizons Histic diagnostic horizons

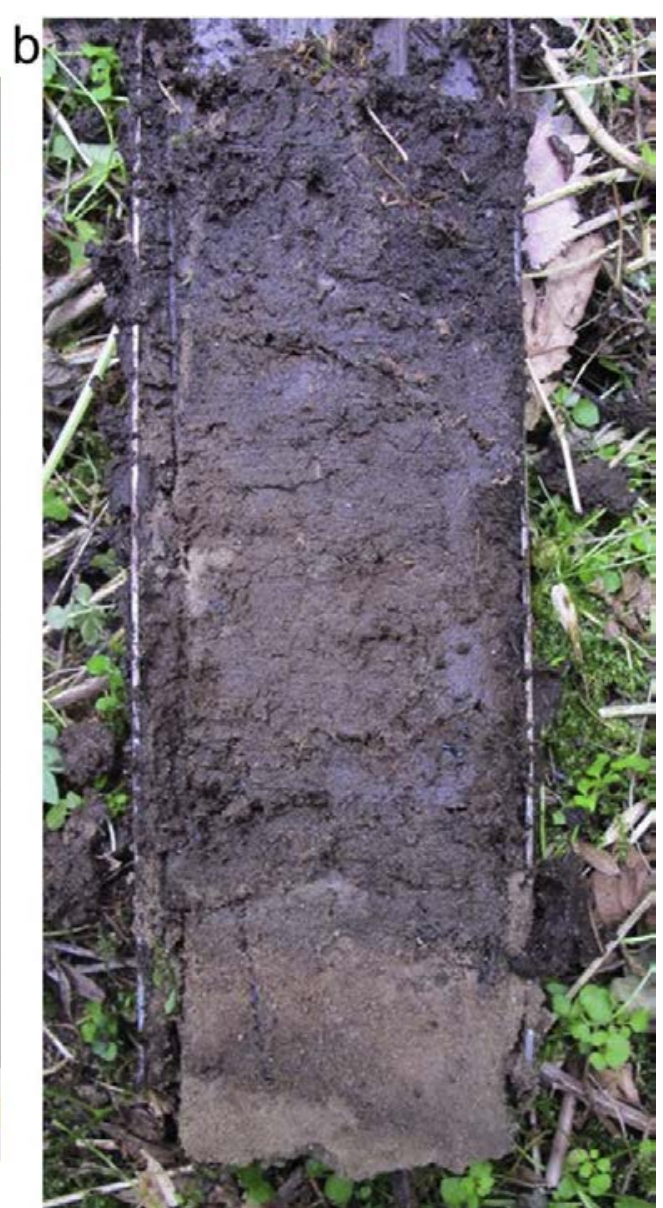

Fig. 2 


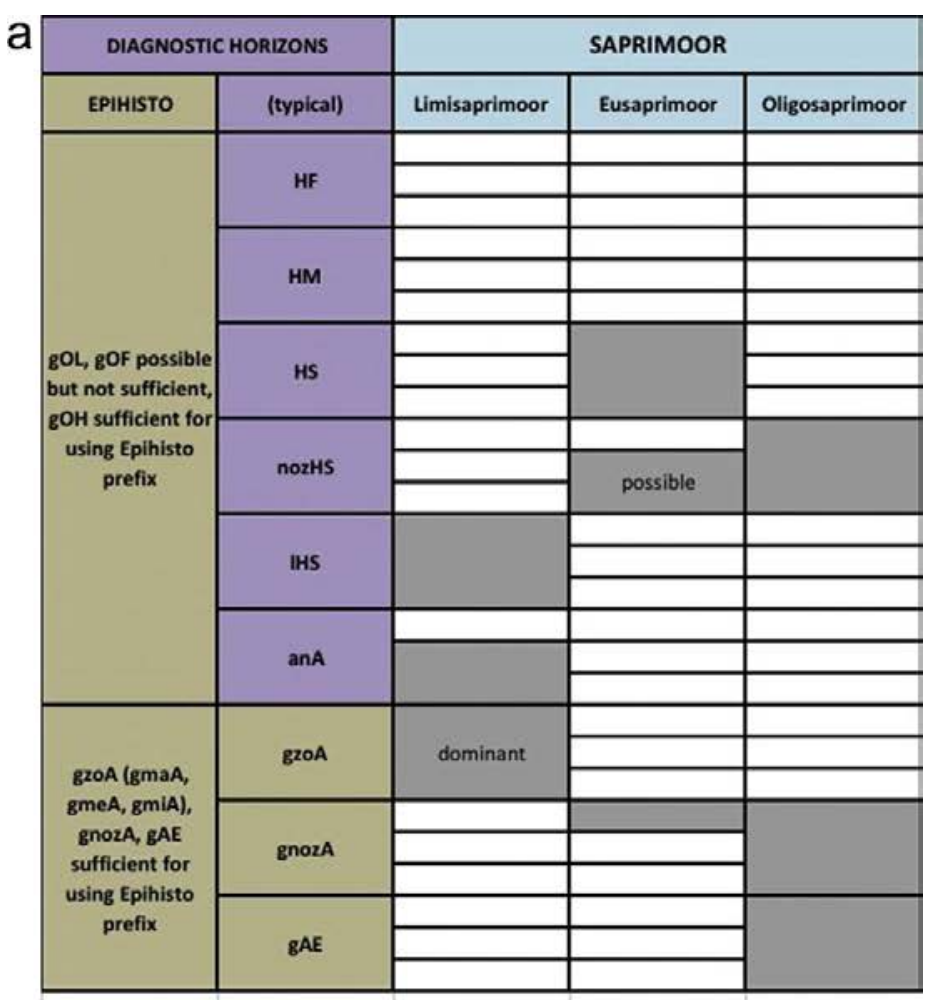

Possible hydromorphic (g) terrestrial diagnostic horizons Histic diagnostic horizons

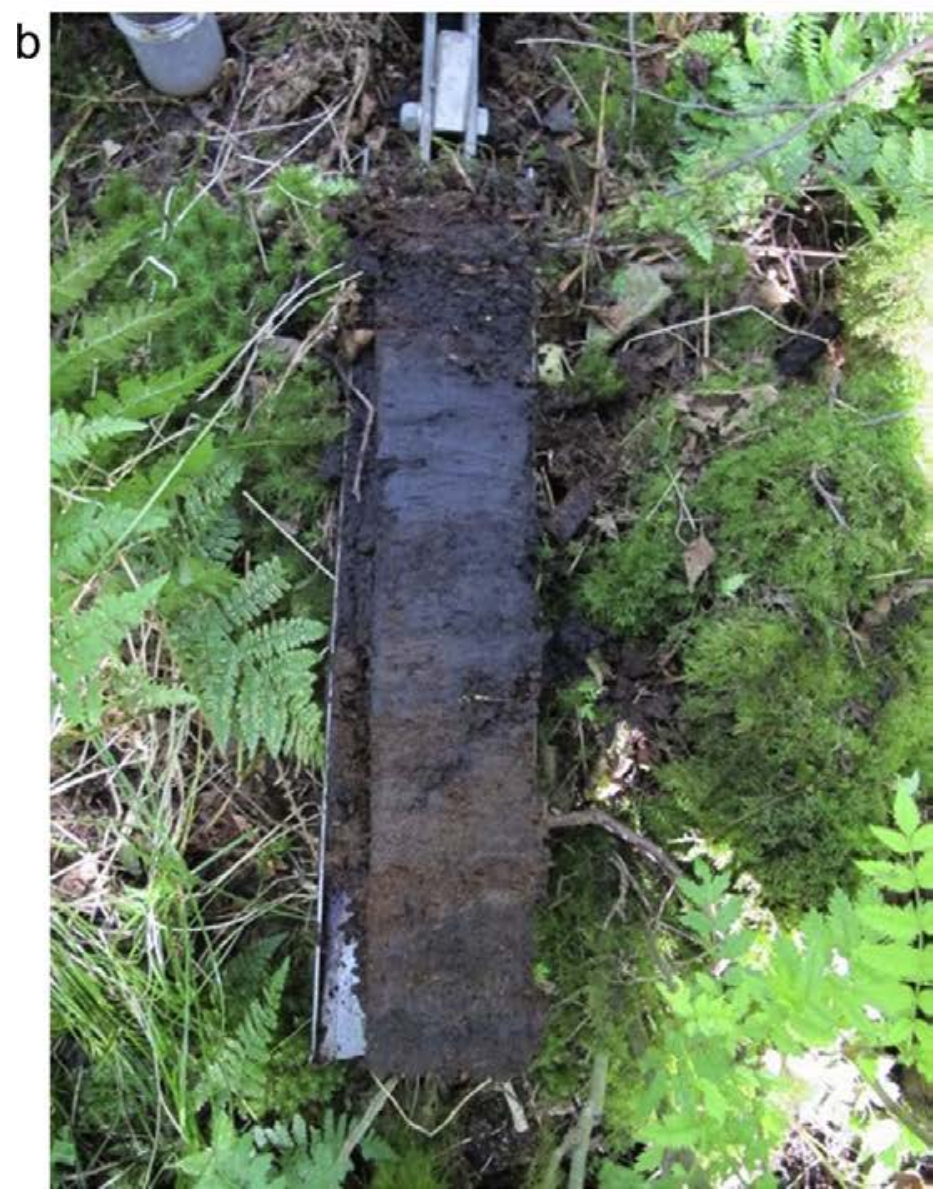

Fig. 3 


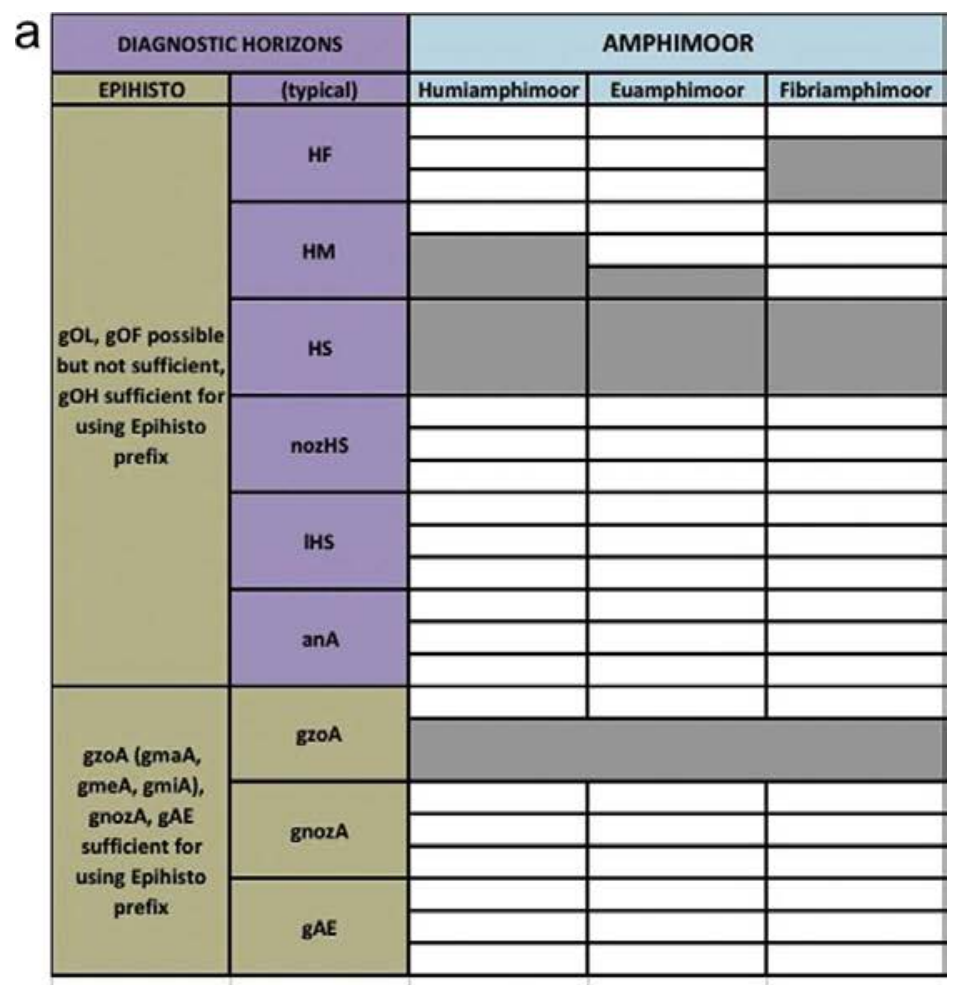

Possible hydromorphic (g) terrestrial diagnostic horizons Histic diagnostic horizons

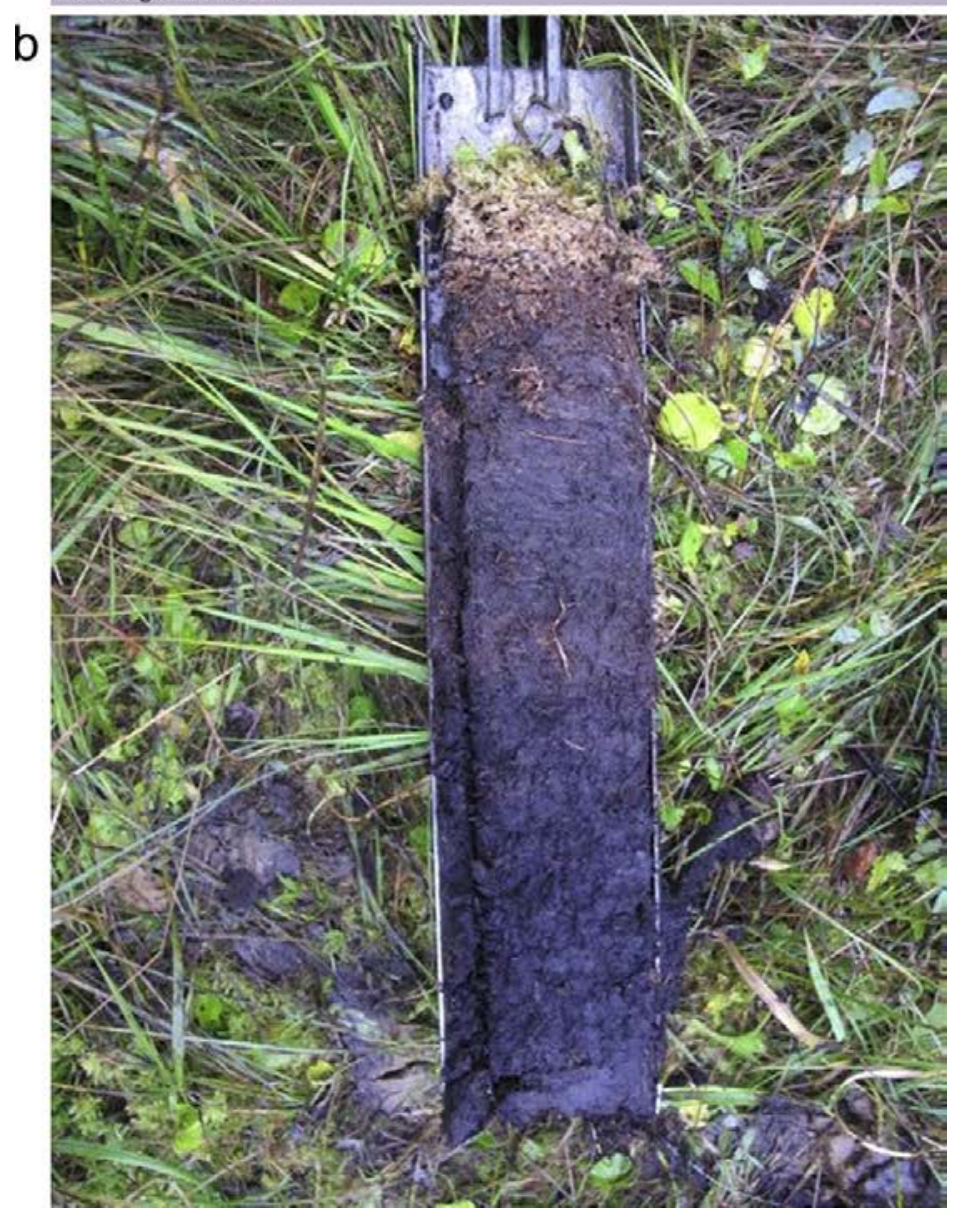

Fig. 4 
a

\begin{tabular}{|c|c|c|c|c|c|}
\hline \multicolumn{2}{|c|}{ OAGGOSTIC HORZONS } & \multicolumn{4}{|c|}{ MESIMOOR } \\
\hline EPIHISTO & (tvpleal) & Soprimesimoor & Humimesimoor & Eumesimoor & Fibrimessimoor \\
\hline \multirow{8}{*}{$\begin{array}{l}80 \mathrm{OOL}, \mathrm{OF} \text { possible } \\
\text { but not sufficient, } \\
\mathrm{gOH} \text { sufficient for } \\
\text { using Epihisto } \\
\text { prefix }\end{array}$} & HF & & & & \\
\hline & нм & & & & \\
\hline & HS & & & & \\
\hline & & & & & \\
\hline & norks & & & & \\
\hline & 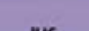 & & & & \\
\hline & & & & & \\
\hline & anA $A$ & & & & \\
\hline \multirow{5}{*}{ 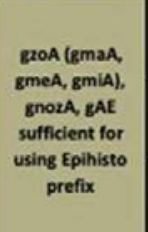 } & & & & & \\
\hline & groA & & & & \\
\hline & $g$ gnora & & & & \\
\hline & & & & & \\
\hline & gAE & & & & \\
\hline
\end{tabular}

Possible hydromorphic (E) terrestrial diagnostic horizons Histic diagnostic horizons

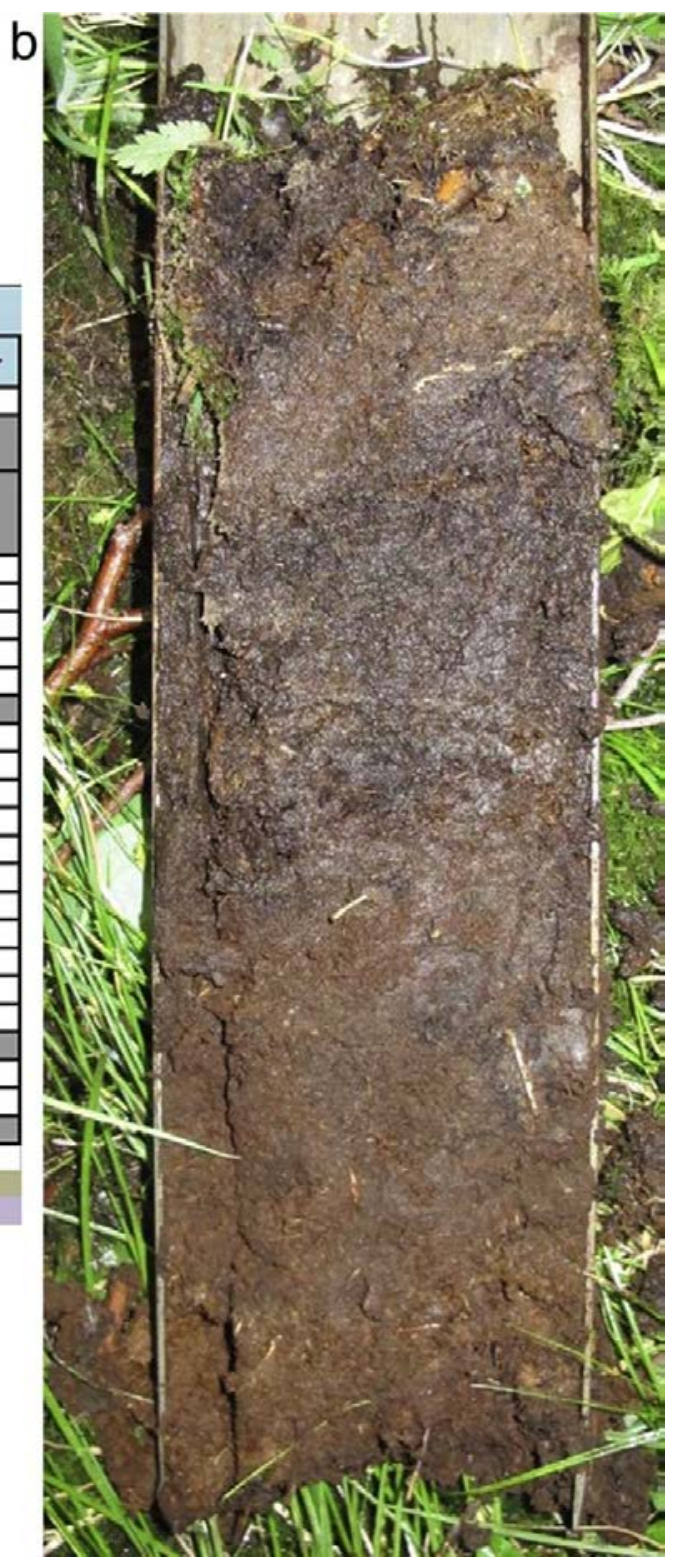

Fig. 5 


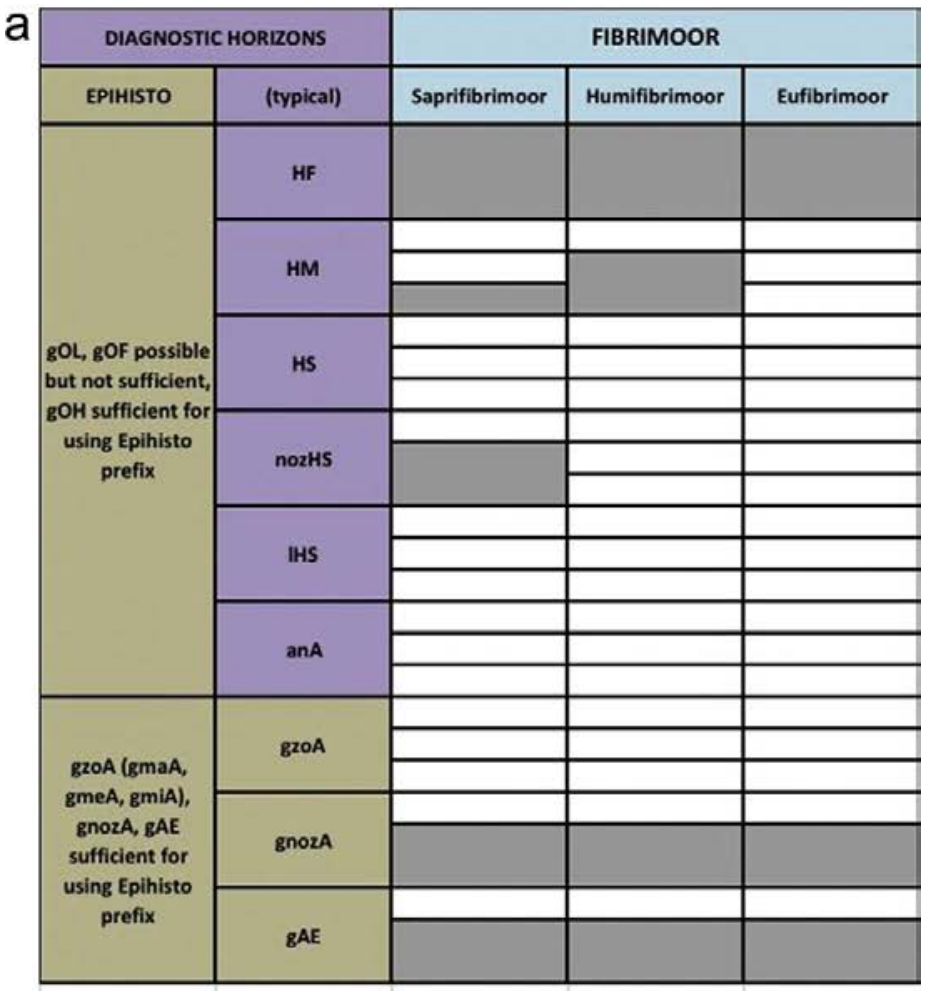

Possible hydromorphic (g) terrestrial diagnostic horizons Histic diagnostic horizons

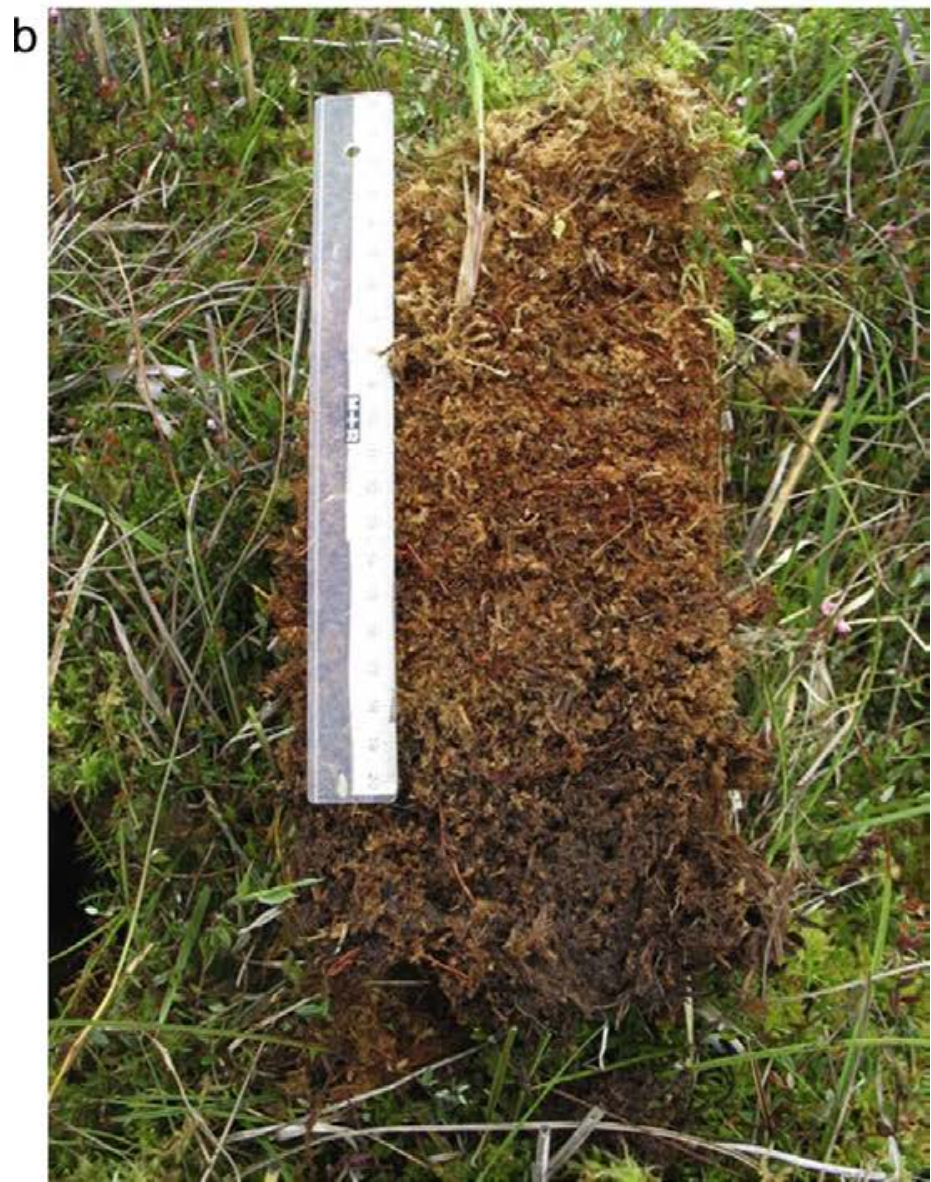

Fig. 6 


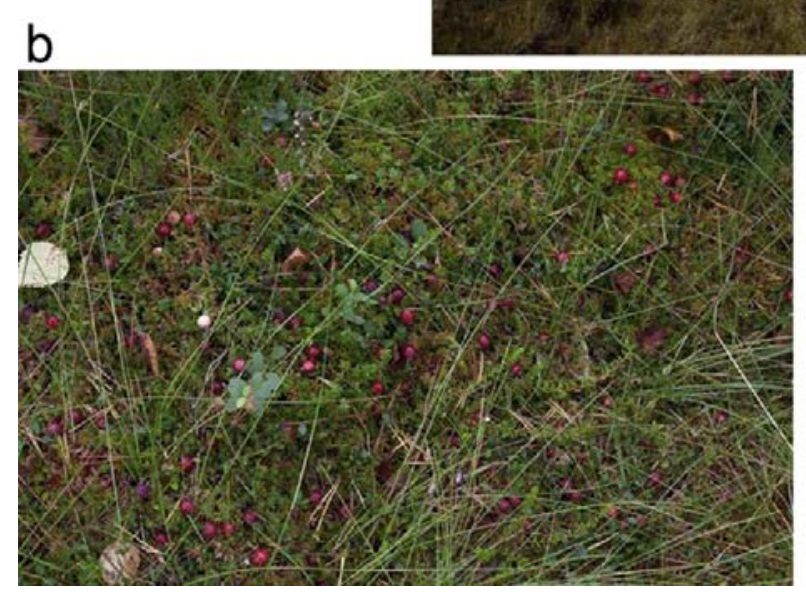

C

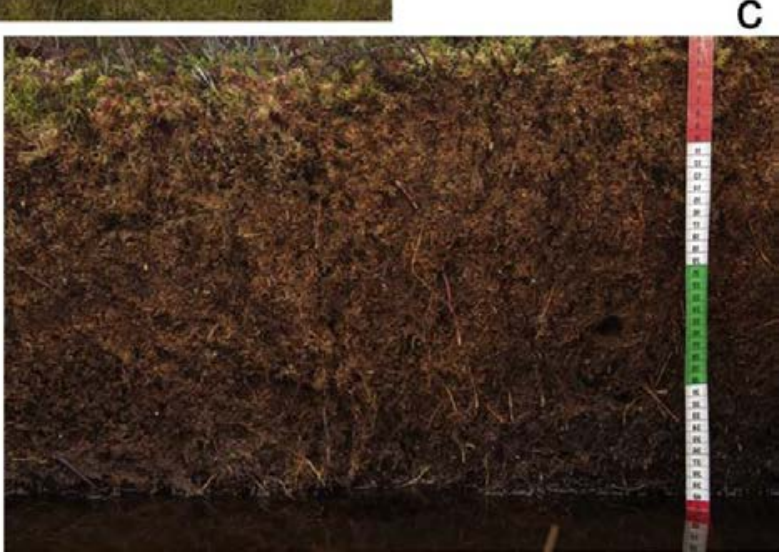

Fig. 7 